\title{
The antecedents of audit quality: The input-process-output factors
}

\author{
M. Ardiansyah Syam ${ }^{a}$, Imam Ghozali ${ }^{b *}$, Adam ${ }^{c}$ and Endang Etty Merawati
}

${ }^{a}$ Senior Lecturer at Faculty of Economics, Pancasila University, Jakarta, Indonesia

${ }^{b}$ Professor in Accounting at The Faculty of Economics and Business, Diponegoro University Indonesia ${ }^{c}$ Senior Lecturer at Accounting Study Program, Swadaya Economic Institute, Jakarta, Indonesia

\section{H R O N I C L E}

\section{Article history:}

Received: January 10, 2021

Received in revised format: April 82021

Accepted: April 12, 2021

Available online:

April 14, 2021

Keywords:

IAASB's Framework for Audit

Quality

Input Factors

Process Factors

Output Factor

Engagement (Auditor) Level

Firm (Public Accounting Firm) Level

\section{A B S T R A C T}

\begin{abstract}
This paper is intended to explore the manifestation of attributes in reflecting audit quality as set by International Auditing and Assurance Standard Board (IAASB). This research focuses on the attributes of Input-Process-Output factors for engagement (auditor) and firm (public accounting firm) level. The input factors considered are: values, ethics, and attitude, knowledge, skill and experience. The process factors considered are: audit process, and quality assurance. The output factor considered is the audit report. The data gathered from 250 senior auditors who work in 100 public accounting firms in Indonesia. The data analysis and hypotheses testing were processed using Second Order Confirmatory Factor Analysis - Structural Equation Model (SEM) - SmartPLS 3.0. The results of the study confirmed that input, process, and output factors manifest the audit quality. All attributes of values, ethics and attitude for engagement and firm level, positively manifest the audit quality. All attributes of knowledge, experience and time, for engagement and firm level, positively manifest the audit quality. All attributes of audit process and quality assurance, for engagement and form level, positively manifest the audit quality. All attributes of output (audit report), for engagement and firm level, positively manifest the audit quality.
\end{abstract}

\section{Introduction}

The term of audit quality is frequently used in debates among scholars, even the stakeholders: regulators, standard setters, audit firms, auditors (Hyun \& Ki-Chang,2020). Audit quality is a complex subject and there is no definition or analysis of it that has achieved universal recognition (IAASB, 2014). The financial information should be relevant, timely and reliable to meet the needs of users. An external audit of the financial information is often required to give users confidence that the information can be trusted. The objective of the audit of financial statements is to form an opinion on the financial statements based on obtained sufficient appropriate audit evidence. The auditors are responsible for performing quality audits of financial statements. The audit quality is best achieved in an environment where there is support from and appropriate interactions among participants in the financial reporting supply chain. There are so many factors that contribute to increasing the quality audits being consistently performed. The IAASB believes there is value in describing these factors and thereby encouraging audit firms and other stakeholders to challenge themselves to increase audit quality in their particular environments. Therefore, the IAASB has undertaken a project to develop a Framework for Audit Quality that describes the input and output factors that contribute to audit quality at the engagement, audit firm and national levels (IAASB, 2014). The auditing standards provide an important foundation in supporting audit quality. The International Standards on Auditing (ISAs) issued by the IAASB describe the 
auditor's objectives and establish minimum requirements. The majority of the requirements in ISAs provide a framework for the judgments to be properly applied. Auditing is a discipline that relies on competent individuals using their experience and applying integrity, objectivity, and skepticism to enable them to make appropriate judgments that are supported by the facts and circumstances of the engagement. Currently, there is no common approach to measuring audit quality. There are a number of initiatives or proposals have been issued by nine bodies world-wide which set out Audit Quality Indicators (AQIs) that might be used to measure audit quality (Federation of European Accountant, 2016). This research focused on the attributes of audit quality set by International Auditing and Assurance Standard Board (IAASB, 2014) and only covers Input-Process-Output Factors for Engagement (Auditor) and Firm (Public Accounting Firm) level.

\section{Literature review}

The two most cited definitions of audit quality have been provided by DeAngelo (1981), who defines audit quality as the joint probability that auditors both investigate or discover a breach in the audited firm's accounting system, and disclose or report the breach through audit opinion. DeFond and Zhang (2013) believe that higher audit quality is greater assurance of high financial reporting quality. (Christensen, et al., 2016) proved that individual investors value auditor competence as an indicator of high audit quality.

\subsection{Framework for Audit Quality (IAASB, 2014)}

The term audit quality encompasses the key elements that create an environment which is audits are performed on a consistent basis. The auditor has to disclose whether the financial statements are free from material misstatement and have to report in accordance with the auditor's findings. The quality audit is achieved by an engagement team (auditor's) that:

1. Exhibited appropriate values, ethics and attitudes;

2. Was sufficiently knowledgeable, skilled, and experienced and had sufficient time allocated to perform the audit work;

3. Applied a rigorous audit process and quality control procedures that complied with law, regulation and applicable standards;

4. Provided useful and timely reports; and

5. Interact appropriately with relevant stakeholders.

Based on IAASB's Framework on Audit Quality (2014), the audit quality depends on Input, Process, and Output factors both engagement level (auditors) and firms' level (public accounting firms). The audit quality also considers the interaction of the stakeholders (auditors, users, regulators, managements and those charged with governance.

\section{Input Factors}

Inputs are grouped into the following input factors:

a. The values, ethics and attitudes of auditors, are influenced by the culture of the audit firm; and

b. The knowledge, skills, and experience of engagement level (auditors) and the time allocated to perform the audit.

\section{Values, Ethics and Attitudes - Engagement Level}

The audit engagement partner is responsible for an audit engagement and therefore is directly responsible for the quality of the audit. Therefore, taking responsibility for the audit quality, the audit engagement partner has a critical role in ensuring that the engagement team (auditors) exhibits the values, ethics and attitudes necessary to support a quality audit. The key attributes are:

- The engagement team recognizes: that the audit is performed in the wider public interest; and the importance of complying with ethical requirements.

- The engagement team exhibits objectivity and integrity.

- The engagement team is independent.

- The engagement team (auditor) exhibits professional competence and due care.

- The engagement team (auditor) exhibits professional skepticism.

Values, Ethics and Attitudes - Firm Level

The culture of audit firm's has an important influence on the values, ethics and attitudes of the engaged team. audit firm's will be an important factor in determining how its team (auditors) function in the public interest and at the same time to achieve the firm's commercial goals (Chae \& Hwang, 2017). The key attributes in relation with the creating a positive culture to audit quality are: 
- Governance arrangements are in place that establish the appropriate "tone at the top", and which aim to safeguard the firm's independence.

- The personal characteristics are promoted through appraisal and reward systems to support audit quality.

- The financial considerations do not drive actions and decisions that impact audit quality.

- The audit firm provides partners and staff with is íp.piprofessional development opportunities and access to high-quality technical support.

- The audit firms promote a positive culture of consultation on difficult issues.

- The robust systems exist to make clients decide on acceptance and continuance.

Knowledge, Skills, Experience and Time - Engagement Level

The audit coordinator is responsible for being satisfied that the engagement team (auditors) collectively has the appropriate competences and has sufficient time to obtain sufficient appropriate audit evidence before judgment or issuing the audit opinion. The key attributes are:

- The partners and staff (audit coordinator and auditors) have the necessary competences

- The partners and staff understand the audited firm's business.

- The partners and staff make reasonable judgments based on appropriate evidence.

- The audit coordinator and auditors are actively involved in risk assessment, planning, supervising, and reviewing the work performed.

- The auditors performing detailed "on-site" audit work has sufficient experience.

Knowledge, Skills, Experience and Time - Firm Level

The policies and procedures of audit firms will impact the required knowledge and experience of audit engagement partners and other members of the engagement team (auditors). The key attributes are:

- The partners and staff (auditor) have sufficient time to deal with difficult issues as they arise.

- $\quad$ The Engagement teams are properly structured.

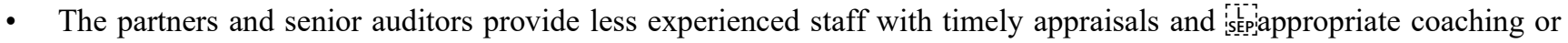
"on-the-job" training.

- The appropriate and sufficient training is given to auditor on audit, accounting and specialized industry issues.

\section{Process Factor}

The audit quality involves auditors to apply a rigorous audit process and quality control procedures that comply with laws, regulations and applicable standards.

\section{Audit Process and Quality Control Procedures - Engagement Level (Auditors)}

The audits need to be performed in accordance with auditing standards and subject to the audit firm's quality control procedures. These procedures provide the foundation for a disciplined approach to risk assessment, planning, performing audit procedures and ultimately forming and expressing an opinion. The audit firms' methodologies and internal policies and procedures provide more specific guidance for those undertaking the audit tasks, internal consultation requirements, and documentation formats. The key attributes are:

- The engaged auditor complies with auditing standards, relevant laws and regulations, and the audit firm's quality control procedures.

- The engaged auditors make appropriate use of information technology.

- The effective interaction with related functions involved in the audit.

- The appropriate arrangements with management to achieve an effective and efficient audit process.

Audit Process and Quality Control Procedures - Firm Level

The policies and procedures of audit firms will impact the audit process. The key attributes are:

- The adaptation of audit methodology to the developments in professional standards and to findings from internal quality control reviews and external inspections. 
- The audit methodology encouragesiseppauditors to apply professional skepticism and exercise appropriate professional judgment.

- The requirement of audit methodology ensures the effective supervision and review of audit work.

- The methodology requires appropriate audit documentation.

- The rigorous quality control procedures are established and audit quality is monitored.

- The effective engagement quality control reviews (EQCRs) are undertaken.

\section{Output Factor}

Output based measures typically cover the material restatements, preferably initiated by the auditor; going concern opinions; and financial reporting characteristics such as the use signed or absolute discretionary accruals. Defond and Zhang (2014) summarize these measures. The researchers or even scholars need to view the audit quality from the perspective of characteristics of the firm and its reporting quality that also affect outputs. (Dichev et al., 2013). The managerial and auditor incentives tend to a non-disclosure of identified misstatements (Srinivasan et al., 2015).

Outputs - Engagement Level

Auditor's Reports to Users of Audited Financial Statements

The most important output of an audit is an auditor's opinion that provides users with confidence and ensures the reliability of the audited financial statements. The value of this signal may be influenced by a number of factors, including the reputation of the audit firm that conducted the audit, and an assumption about the effectiveness of the audit process employed.

- Auditor's Reports to Those Charged with Governance

The standard of auditing requires the auditor to communicate with those charged with governance on specific matters on a regular basis. For example, ISAs require communication about:

- $\quad$ The auditor's responsibilities.

- $\quad$ The scope and timing of the audit (planned schedule).

- The information about the auditor's independence and objectivity.

- $\quad$ The significant findings from the audit.

- Auditor's Reports to Management

During the course of the audit, the auditor will also have extensive communication with management. The communication between the audit firm and management are usually informal. Besides, to formalize the communication, the auditor may decide, or management may request, the auditor observations in a written report. Auditor's Reports to Financial and Prudential Regulators.

\section{Conceptual framework and hypotheses development}

In terms of audit quality, the accounting research, commonly, investigates the drivers and consequences of audit quality (Muliati et al., 2021). The most common proxies for audit quality were categorized into input-based proxies and output-based proxies (Defond \& Zhang 2014). The input-based proxies refer to auditor-specific characteristics, and auditor fees. Mostly, the scholars or researchers measure the auditor-specific characteristics using auditor size, whether the company is audited by a Big 4 auditor or not (Defond et al., 2014). This research focused on the attributes of audit quality set by International Auditing and Assurance Standard Board (IAASB, 2014) and only covers Input-Process-Output Factors for Engagement (Auditor) and Firm (Public Accounting Firm) level. Based on the conceptual framework, the hypotheses of this research are defined as follows:

Hypothesis 1: The attributes of values, ethics and attitude of engagement level (auditor) positively manifest the audit quality.

Hypothesis 2: The attributes of values, ethics and attitude of firm level (public accounting firm) positively manifest the audit quality.

Hypothesis 3: The attributes of knowledge, experience, and time of engagement level (auditor) positively manifest the audit quality.

Hypothesis 4: The attributes of knowledge, experience, and time of firm level (public accounting firm) positively manifest the audit quality. 
Hypothesis 5: The attributes of audit process and quality assurance of engagement level (auditor) positively manifest the audit quality.

Hypothesis 6: The attributes of audit process and quality assurance of firm level (public accounting firm) positively manifest the audit quality.

Hypothesis 7: The attributes of output (audit report) of engagement level (auditor) positively manifest to the audit quality.

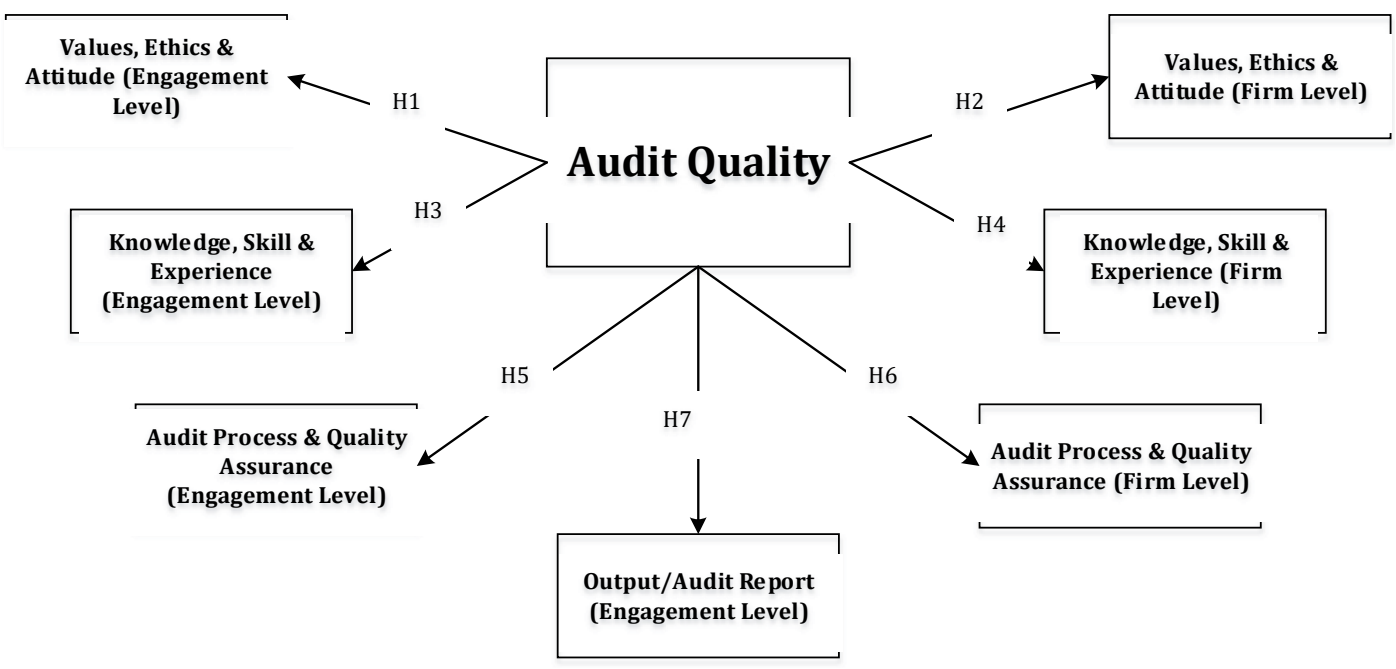

Fig. 1. Conceptual Framework

\section{Methodology}

\subsection{Data Collection}

The data was gathered from 250 senior auditors of 100 Public Accounting Firm in Indonesia. Questionnaires were sent to 300 respondents and 270 returned the questionnaire. There were 250 questionnaires that were fulfilled and used for the analysis.

\subsection{Measurement}

The attributes of Input-Process-Output Factors for engagement (auditor) and firm (public accounting firm) level as set by IAASB 2014. All attributes of Input-Process-Output factors for engagement (auditor) and firm (public accounting firm) as defined in Framework for Audit Quality by IAASB (2014) were measured using 5 point Likert scale.

\section{Data analysis and interpretation}

\subsection{Data Analysis}

The Second Order Confirmatory Factor Analysis (Second Order CFA) was used to test the proposed hypotheses. First, we test the significance of the outer loading of all attributes in reflecting/manifesting input-process and output factors of audit quality. Secondly, we test the significance of the factors in reflecting/manifesting the audit quality.

\section{Table 1}

Reliability, Internal Consistency and Average Variance Extracted

\begin{tabular}{|c|c|c|c|c|}
\hline & AVE & R Squared & $\begin{array}{c}\text { Cronbach } \\
\text { Alpha } \\
\end{array}$ & $\begin{array}{l}\text { Composite } \\
\text { Reliability }\end{array}$ \\
\hline Value, Ethics and Attitudes (Eng Level) & 0.620 & 0.631 & 0.838 & 0.887 \\
\hline Value. Ethics and Attitudes (Firm Level) & 0.544 & 0.620 & 0.825 & 0.875 \\
\hline Knowledge, Skills and Experience (Firm Level) & 0.445 & 0.858 & 0.782 & 0.846 \\
\hline Knowledge, Skills and Experience (Eng Level) & 0.573 & 0.728 & 0.749 & 0.842 \\
\hline Audit Process and Quality Assurance(Eng Level) & 0.438 & 0.606 & 0.678 & 0.793 \\
\hline Audit Process and Quality Assurance(Firm Level) & 0.521 & 0.725 & 0.811 & 0.865 \\
\hline Output/Audit Report (Eng Level) & 0.667 & 0.751 & 0.834 & 0.889 \\
\hline
\end{tabular}




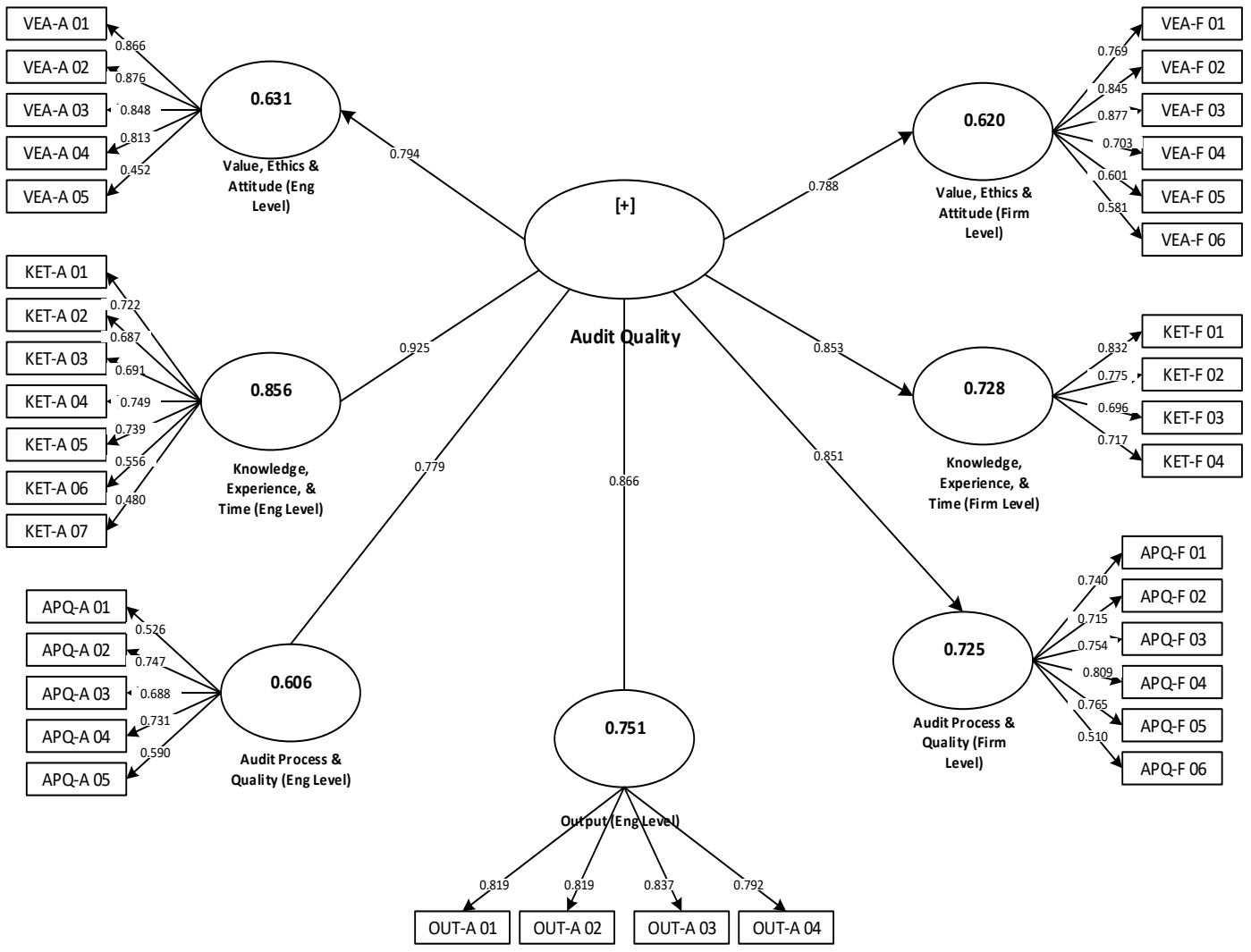

Fig. 2. Second Order Confirmatory Factor Analysis of Attributes of Audit Quality

The Attributes of Audit Quality - First Order Confirmatory Factor Analysis

The Attributes of Values, Ethics, and Attitude - Engagement Level

To test the significance of attribute in reflecting/manifesting the latent variables, the $t_{\text {statistic }}$ must be higher than 1.96 and probability (p-values) must be lower than 0.005 .

Table 2

The Manifestation of Attributes of Values, Ethics and Attitude for Engagement (Auditor) Level

\begin{tabular}{|c|c|c|c|c|}
\hline & Original Sample & Sample Mean & Standard Deviation & P value \\
\hline VEA-A $\leftarrow$ Audit Quality & 0.774 & 0.775 & 0.047 & 0.000 \\
\hline VEA-A01 $\leftarrow$ Value. Ethics and Attitudes (Eng Level) & 0.868 & 0.867 & 0.039 & 0.000 \\
\hline VEA-A02 $\leftarrow$ Value. Ethics and Attitudes (Eng Level) & 0.876 & 0.875 & 0.031 & 0.000 \\
\hline VEA-A03 $\leftarrow$ Value. Ethics and Attitudes (Eng Level) & 0.848 & 0.847 & 0.04 & 0.000 \\
\hline VEA-A04 $\leftarrow$ Value. Ethics and Attitudes (Eng Level) & 0.813 & 0.815 & 0.036 & 0.000 \\
\hline VEA-A05 $\leftarrow$ Value. Ethics and Attitudes (Eng Level) & 0.452 & 0.440 & 0.099 & 0.000 \\
\hline
\end{tabular}

The Attributes of Values, Ethics, and Attitude - Firm Level

The loading factor (original sample and sample mean) indicates the degree of of attributes in manifesting/reflecting the factors.

Table 3

The Manifestation of Attributes of Values, Ethics and Attitude for Engagement (Public Accounting Firm) Level

\begin{tabular}{|c|c|c|c|c|}
\hline & Original Sample & Sample Mean & $\begin{array}{l}\text { Standard } \\
\text { Deviation }\end{array}$ & P value \\
\hline VEA-F $\leftarrow$ Audit Quality & 0.779 & 0.776 & 0.045 & 0.000 \\
\hline VEA-F $01 \leftarrow$ Value. Ethics and Attitudes (Firm Level) & 0.769 & 0.768 & 0.036 & 0.000 \\
\hline VEA-F $02 \leftarrow$ Value. Ethics and Attitudes (Firm Level) & 0.854 & 0.844 & 0.033 & 0.000 \\
\hline VEA-F $03 \leftarrow$ Value. Ethics and Attitudes (Firm Level) & 0.877 & 0.874 & 0.027 & 0.000 \\
\hline VEA-F $04 \leftarrow$ Value. Ethics and Attitudes (Firm Level) & 0.703 & 0.702 & 0.066 & 0.000 \\
\hline VEA-F $05 \leftarrow$ Value. Ethics and Attitudes (Firm Level) & 0.601 & 0.600 & 0.058 & 0.000 \\
\hline VEA-F $06 \leftarrow$ Value. Ethics and Attitudes (Firm Level) & 0.581 & 0.578 & 0.081 & 0.000 \\
\hline
\end{tabular}


The loading factor (original sample and sample mean) indicates the degree of of attributes in manifesting/reflecting the factors. The $t_{\text {statistic }}$ or $t_{\text {value }}$ of the attributes of knowledge, skills, and experience for engagement (Auditor) level are shown in the table below.

Table 4

The Manifestation of Attributes of Knowledge, Skills, and Experience for Engagement (Auditor) Level

\begin{tabular}{|c|c|c|c|c|}
\hline & Original Sample & Sample Mean & Standard & P value \\
\hline KET-A $\leftarrow$ Audit Quality & 0.991 & 0.912 & 0.016 & 0.000 \\
\hline KET-A- $01 \leftarrow$ Knowledge, Skills and Experience (Eng Level) & 0.722 & 0.718 & 0.064 & 0.000 \\
\hline KET-A- $02 \leftarrow$ Knowledge, Skills and Experience (Eng Level) & 0.687 & 0.684 & 0.069 & 0.000 \\
\hline KET-A- $03 \leftarrow$ Knowledge, Skills and Experience (Eng Level) & 0.691 & 0.694 & 0.052 & 0.000 \\
\hline KET-A- $04 \leftarrow$ Knowledge, Skills and Experience (Eng Level) & 0.749 & 0.746 & 0.045 & 0.000 \\
\hline KET-A- $05 \leftarrow$ Knowledge, Skills and Experience (Eng Level) & 0.739 & 0.740 & 0.053 & 0.000 \\
\hline KET-A- $06 \leftarrow$ Knowledge, Skills and Experience (Eng Level) & 0.556 & 0.558 & 0.082 & 0.000 \\
\hline KET-A- $07 \leftarrow$ Knowledge, Skills and Experience (Eng Level) & 0.480 & 0.490 & 0.098 & 0.000 \\
\hline
\end{tabular}

\subsection{The attributes of Knowledge, Skill, \& Experience (Firm Level)}

The loading factor (original sample and sample mean) indicates the degree of of attributes in manifesting/reflecting the factors.

Table 5

The Manifestation of Attributes of Knowledge, Skills, and Experience for Firm (Public Accounting Firm) Level

\begin{tabular}{|c|c|c|c|c|}
\hline & Original Sample & Sample Mean & $\begin{array}{l}\text { Standard } \\
\text { Deviation } \\
\end{array}$ & P value \\
\hline KET-F $\leftarrow$ Audit Quality & 0.991 & 0.912 & 0.016 & 0.000 \\
\hline KET-F- $01 \leftarrow$ Knowledge, Skills and Experience (Firm Level) & 0.722 & 0.718 & 0.064 & 0.000 \\
\hline KET-F- $02 \leftarrow$ Knowledge, Skills and Experience (Firm Level) & 0.687 & 0.684 & 0.069 & 0.000 \\
\hline KET-F- $03 \leftarrow$ Knowledge, Skills and Experience (Firm Level) & 0.691 & 0.694 & 0.052 & 0.000 \\
\hline KET-F- $04<$ Knowledge, Skills and Experience (Firm Level) & 0.749 & 0.746 & 0.045 & 0.000 \\
\hline
\end{tabular}

The attributes of Audit Process and Quality Assurance (Engagement Level)

The $t_{\text {statistic }}$ or $t_{\text {value }}$ of the attributes of audit process and quality assurance for engagement level are shown in the table below.

Table 6

The Manifestation of Attributes of Audit Process and Quality Assurance for Engagement (Auditor) Level

\begin{tabular}{|c|c|c|c|c|}
\hline & Original Sample & Sample Mean & $\begin{array}{l}\text { Standard } \\
\text { Deviation }\end{array}$ & P value \\
\hline APQ-A $\leftarrow$ Audit Quality & 0.755 & 0.753 & 0.054 & 0.000 \\
\hline APQ-A01 $\leftarrow$ Audit Process and Quality Assurance (Eng Level) & 0.526 & 0.518 & 0.111 & 0.000 \\
\hline APQ-A02 $\leftarrow$ Audit Process and Quality Assurance (Eng Level) & 0.747 & 0.747 & 0.059 & 0.000 \\
\hline APQ-A03 $\leftarrow$ Audit Process and Quality Assurance (Eng Level) & 0.688 & 0.688 & 0.070 & 0.000 \\
\hline APQ-A04 $\leftarrow$ Audit Process and Quality Assurance (Eng Level) & 0.731 & 0.731 & 0.052 & 0.000 \\
\hline APQ-A05 $\leftarrow$ Audit Process and Quality Assurance (Eng Level) & 0.590 & 0.586 & 0.080 & 0.000 \\
\hline
\end{tabular}

\subsection{The attributes of Audit Process and Quality Assurance (Firm Level)}

The $t_{\text {statistic }}$ or $t_{\text {value }}$ of the attributes of audit process and quality assurance for firm level are shown in the table below.

\section{Table 7}

The Manifestation of Attributes of Audit Process and Quality Assurance for Firm (Public Accounting Firm) Level

\begin{tabular}{|c|c|c|c|c|}
\hline & Original Sample & Sample Mean & $\begin{array}{l}\text { Standard } \\
\text { Deviation }\end{array}$ & P value \\
\hline APQ-E $\leftarrow$ Audit Quality & 0.845 & 0.848 & 0.032 & 0.000 \\
\hline APQ-F01 $\leftarrow$ Audit Process and Quality Assurance (Firm Level) & 0.740 & 0.733 & 0.060 & 0.000 \\
\hline APQ-F02 $\leftarrow$ Audit Process and Quality Assurance (Firm Level) & 0.715 & 0.717 & 0.057 & 0.000 \\
\hline APQ-F03 $\leftarrow$ Audit Process and Quality Assurance (Firm Level) & 0.754 & 0.758 & 0.036 & 0.000 \\
\hline APQ-F04 $\leftarrow$ Audit Process and Quality Assurance (Firm Level) & 0.809 & 0.807 & 0.036 & 0.000 \\
\hline APQ-F05 $\leftarrow$ Audit Process and Quality Assurance (Firm Level) & 0.765 & 0.765 & 0.045 & 0.000 \\
\hline APQ-F06 $\leftarrow$ Audit Process and Quality Assurance (Firm Level) & 0.510 & 0.508 & 0.045 & 0.000 \\
\hline
\end{tabular}


The $t_{\text {statistic }}$ or $t_{\text {value }}$ of the attributes of output/audit report for engagement level are shown in the table below.

Table 8

The Manifestation of Attributes of Output/Audit Report for Engagement (Auditor) Level

\begin{tabular}{|c|c|c|c|c|}
\hline & Original Sample & Sample Mean & $\begin{array}{l}\text { Standard } \\
\text { Deviation }\end{array}$ & P value \\
\hline OUT-A $\leftarrow$ Audit Quality & 0.861 & 0.860 & 0.024 & 0.000 \\
\hline OUT-A01 $\leftarrow$ Output $($ ENG Level) & 0.819 & 0.819 & 0.040 & 0.000 \\
\hline OUT-A02 $\leftarrow$ Output (ENG Level) & 0.819 & 0.819 & 0.037 & 0.000 \\
\hline OUT-A03 $\leftarrow$ Output (ENG Level) & 0.837 & 0.836 & 0.033 & 0.000 \\
\hline OUT-A0S $\leftarrow$ Output (ENG Level) & 0.792 & 0.789 & 0.038 & 0.000 \\
\hline
\end{tabular}

Based on the first order confirmatory analysis, the loading factors of all attributes manifested the input-process and output/audit both for engagement (auditor) and public accounting firm (firm) level manifested the audit quality.

\subsection{Hypotheses Testing - Second Order Confirmatory Factor Analysis}

To test the hypothesis, we can see the inner loading factors and significant level ( $\left.\mathrm{t}_{\mathrm{stat}} \mathrm{stic}_{\mathrm{ic}}\right)$. The effect of the construct is statistically significant if the $t_{\text {statistic }}$ is higher than 1.96 and $p_{\text {values }}$ lower than 0.05 at confidence interval $95 \%$. The result of hypotheses testing using second order component factor analysis were shown in the table below.

\section{Table 9}

The Result of Hypotheses Testing

\begin{tabular}{|c|c|c|c|c|}
\hline & $\begin{array}{c}\text { Original } \\
\text { Sample }\end{array}$ & Sample Mean & $\begin{array}{l}\text { Standard } \\
\text { Deviation }\end{array}$ & P value \\
\hline Audit Quality $\rightarrow$ Value. Ethics and Attitudes (Eng Level) & 0.794 & 0.795 & 0.040 & 0.000 \\
\hline Audit Quality $\rightarrow$ Value. Ethics and Attitudes (Firm Level) & 0.788 & 0.787 & 0.044 & 0.000 \\
\hline Audit Quality $\rightarrow$ Knowledge, Skills and Experience (Eng Level) & 0.925 & 0.926 & 0.014 & 0.000 \\
\hline Audit Quality $\rightarrow$ Knowledge, Skills and Experience (Firm Level) & 0.853 & 0.854 & 0.024 & 0.000 \\
\hline Audit Quality $\rightarrow$ Audit Process and Quality Assurance (Eng Level) & 0.779 & 0.779 & 0.047 & 0.000 \\
\hline Audit Quality $\rightarrow$ Audit Process and Quality Assurance (Firm Level) & 0.851 & 0.851 & 0.029 & 0.000 \\
\hline Audit Quality $\rightarrow$ Output/Audit Report (Eng Level) & 0.866 & 0.869 & 0.021 & 0.000 \\
\hline
\end{tabular}

The result of the second order confirmatory factor analysis in PLS shows that the loading factor (manifestation) of audit quality reflected by values, ethics, and attitudes for engagement (Auditor) level is 0.794 and $t_{\text {statistic }}$ is 19.923 and $p_{\text {value }}$ is 0.000 . Statistically, the Hypothesis 1: The attributes of values, ethics and attitudes for engagement (auditor) level positively manifest the audit quality was supported.

The loading factor (manifestation) of audit quality reflected by values, ethics, and attitudes for firm (public accounting firm) level is 0.788 and $t_{\text {statistic }}$ is 10.080 and $p_{\text {value }}$ is 0.000 . Statistically, the Hypothesis 2: The attributes of values, ethics and attitudes for firm (public accounting firm) level positively manifest the audit quality was supported.

The loading factor (manifestation) of audit quality reflected by knowledge, skills, and experience for engagement (Auditor) level is 0.925 and $t_{\text {statistic }}$ is 67.326 and $p_{\text {value }}$ is 0.000 . Statistically, the Hypothesis 3: The attributes of knowledge, skills, and experience for engagement (Auditor) level positively manifest the audit quality was supported.

The loading factor (manifestation) of audit quality reflected by knowledge, skills, and experience for firm (public accounting firm) level is 0.853 and $t_{\text {statistic }}$ is 34.821 and $p_{\text {value }}$ is 0.000 . Statistically, the Hypothesis 4: The attributes of knowledge, skills, and experience for form (public accounting firm) level positively manifest the audit quality was supported.

The loading factor (manifestation) of audit quality reflected by audit process and quality assurance for engagement (Auditor) level is 0.779 and $t_{\text {statistic }}$ is 16.585 and $p_{\text {value }}$ is 0.000 . Statistically, the Hypothesis 5: The attributes of audit process and quality assurance for engagement (Auditor) level positively manifest the audit quality was supported.

The loading factor (manifestation) of audit quality reflected by audit process and quality assurance for firm (public accounting firm) level is 0.851 and $t_{\text {statistic }}$ is 29.938 and $p_{\text {value }}$ is 0.000 . Statistically, the Hypothesis 6: The attributes of audit process and quality assurance for firm (public accounting firm) level positively manifest the audit quality was supported. 
The loading factor (manifestation) of audit quality reflected by output/audit report for engagement (Auditor) level is 0.866 and $t_{\text {statistic }}$ is 40.566 and $p_{\text {value }}$ is 0.000 . Statistically, the Hypothesis 7: The attributes of output/audit report for engagement (auditor) level positively manifest the audit quality was supported.

\section{Discussion and conclusion}

The audit quality must be a common concern of all stakeholders: auditors, public accounting firms, management of companies (clients), investors, even the regulator (government). There were so many indicators of audit quality as set by several regulator bodies. The attributes and indicators of audit quality must be set not only by regulator, but also academics and practitioners (Wooten, 2003; IAASB, 2013; IAASB, 2014; van Raak and Thurheimer, 2016; Malaysian Institute of Accountant, 2016; Federation of European Accountant, 2017).

The auditors play the most important role in determining the audit quality during the auditing process (Gul et al., 2013; Gold et al., 2017). Knowledge, skills and experiences of the auditor were the highest factor in manifesting/reflecting audit quality for both engagement (auditor) and firm (public accounting firm. In terms of input factor, knowledge, skills and experiences of the auditor play a more important role in producing qualified audit reports rather than values, ethics, and attitude of auditors.

In term of audit firm, the tenure and size also reflect the audit quality (DeAngelo, 1981; Gosh \& Moon, 2005; Stanley \& DeZoort, 2007; Rohami, et al., 2009; Fernando et al., 2010; Lim \& Tan, 2010; Dechow et al., 2011; Abedalqader et al., 2011; Junaidi \& Hartadi, 2012; Siregar et al., 2012; Bell et al., 2015; Lee, 2015; Gonzalez-Diaz, 2015; Hohenfels, 2016; Garcia-Blandon et al., 2017, Ji-Hang, 2019)). Experience and competency of auditor also reflected the audit quality (Francis, 2004; Le et al., 2009; Furiady \& Kurnia, 2015).

The complete output/audit report, that was given to users of audited financial reports, to those charged with governance, to management, and to financial and prudential regulators, reflected/manifested the audit quality. In the term of output, the competent auditor plays an important role in producing the qualified audit reports (Kilgore \& Radich, 2011; Kilgore \& Radich, 2014).

The management of public accounting firms (firm level) plays an important role in setting the standard of audit process and quality assurance. The commitment of the management in setting the audit process and quality standard of audit reporting. The role of firm or regulator in setting the audit quality standard also found by (Carcello et al., 1992; IAASB, 2014; Sarwoko \& Agoes, 2014; PWC Indonesia, 2017; Prayogo \& Agus 2017)

The attributes of values, ethics and attitude also reflected/manifested audit quality. Independency and integrity of auditors play an important role in determining the audit quality. The results were also proven by (Chen et al., 2005; Daniels \& Booker, 2011; Jamal \& Sunder, 2011; Suseno, 2013; Lin \& Tepalagul, 2015; Rahmina et al., 2015; Saputra, 2015; Patrick et al., 2017). The ethics for firm (public accounting firm) level also contribute to audit quality through the reduction of dysfunctional audit behavior (Adnan, 2012; Morris 2014, Faisal et al., 2017; Ghosh \& Moon, 2005).

This study only focused attributes of Input-Process-Output Factors for engagement (auditor) and firm (public accounting firm) level. The future research is suggested to explore the interaction among factors and the environment of the auditing process. The future researches have to involve the regulator and broaden to national level.

\section{References}

Abedalqader Al-Thuneibat, A., Tawfiq Ibrahim Al Issa, R., \& Ata Baker, R. A. (2011). Do audit tenure and firm size contribute to audit quality? Managerial Auditing Journal, 26(4), 317-334.

Bell, T. B., Causholli, M., \& Knechel, W. R. (2015). Audit Firm Tenure, Non-Audit Services, and Internal Assessments of Audit Quality. Journal of Accounting Research, 53(3), 461-509.

Carcello, J. V, Hermanson, R. H., \& McGrath, N. T. (1992). Audit Quality Attributes: The Perceptions of Audit Partners, Preparers, and Financial Statement Users. Auditing: A Journal of Practice \& Theory, 11(1), 1-15.

Chae, S. J., \& Hwang, H. J. (2017). The effect of audit quality on crash risk: Focusing on distribution \& service companies. The Journal of Distribution Science, 15(8), 47-54.

Chen, K. Y., Elder, R. J., \& Liu, J.-L. (2005). Auditor Independence, Audit Quality and Auditor-Client Negotiation Outcomes: Some Evidence from Taiwan. Journal of Contemporary Accounting \& Economics, 1(2), 119-146.

Christensen, B. E., Glover, S. M., Omer, T. C., \& Shelley, M. K. (2016). Understanding Audit Quality: Insights from Audit Professionals and Investors. Contemporary Accounting Research, 33(4), 1648-1684. 
Daniels, B. W., \& Booker, Q. (2011). The effects of audit firm rotation on perceived auditor independence and audit quality. Research in Accounting Regulation, 23(1), 78-82.

DeAngelo, L. E. (1981). Auditor size and audit quality. Journal of Accounting and Economics, 3(3), $183-199$.

Dechow, P. M., Ge, W., Larson, C. R., \& Sloan, R. G. (2011). Predicting Material Accounting Misstatements. Contemporary Accounting Research, 28(1), 17-82.

DeFond, M., Erkens, D. H., \& Zhang, J. (2014). Do client characteristics really drive Big N quality differentiation. University of Southern California.

Faisal, F. (2017). The Impact of Authentic Leadership, Corporate Ethical Values, Employee Incentives and Workload/Task Complexity on Dysfunctional Auditor Behavior. International Journal of Economic Research, 14(9).

Federation of European Accountant (2016). Overview of Audit Quality Indicators Initiatives Update. Audit \& Assurance, (December 2015), 1-21.

Fernando, G. D., Abdel-Meguid, A. M., \& Elder, R. J. (2010). Audit quality attributes, client size and cost of equity capital. Review of Accounting \& Finance, 9(4), 363-381.

Francis, J. R. (2004). What do we know about audit quality? British Accounting Review.

Furiady, O., \& Kurnia, R. (2015). The Effect of Work Experiences, Competency, Motivation, Accountability and Objectivity towards Audit Quality. Procedia - Social and Behavioral Sciences, 211, 328-335.

Garcia-Blandon, J., \& Argiles-Bosch, J. M. (2017). The interaction effects of firm and partner tenure on audit quality. Accounting and Business Research, 47(7), 810-830.

Ghosh, A., \& Moon, D. (2005). Auditor tenure and perceptions of audit quality. Accounting Review, 80(2), 585-612.

Gold, A., Kuang, Y. F., Lee, G., \& Qin, B. (2017). Do Satisfied Auditors Perform Better? Investigating the Association between Audit Firm Employee Job Satisfaction and Audit Quality. Working Paper.

González-Díaz, B., García-Fernández, R., \& López-Díaz, A. (2015). Auditor tenure and audit quality in Spanish state-owned foundations. Revista de Contabilidad, 18(2), 115-126.

Gul, F. A., Wu, D., \& Yang, Z. (2013). Do individual auditors affect audit quality? Evidence from archival data. Accounting Review, 88(6), 1993-2023.

Hohenfels, D. (2016). Auditor Tenure and Perceived Earnings Quality. International Journal of Auditing, 20 (3), $224-238$.

Hyun, J.S., \& Ki-Chang,Y. (2020). The Effects of Widening Daily Stock Price Limits on the Relevance between Audit Quality and Stock Return. The Journal of Asian Finance, Economics and Business, 7(4).

IAASB. (2013). A framework for audit quality: Consultation Paper, 1-72.

IAASB. (2013). Framework for Audit Quality: Key Elements that Create an Environment for Audit Quality, 1-13.

IAASB. (2014). Framework for Audit Quality: Key Elements that Create an Environment for Audit Quality, 1-63.

Jamal, K., \& Sunder, S. (2011). Is mandated independence necessary for audit quality? Accounting, Organizations and Society, 36(4-5), 284-292.

JI_Hang, S. (2019). Market Competition and Audit Quality in Distribution and Service Industries. 유통과학연구 / v.17, no.4, Year, pp. https://doi.org/10.15722/jds.17.4.201904.33

Junaidi, Miharjo, S., \& Hartadi, B. (2012). Does auditor tenure reduce audit quality? Gadjah Mada International Journal of Business, 14(3), 303-315.

Kilgore, A., Harrison, G., \& Radich, R. (2014). Audit quality: what's important to users of audit services. Managerial Auditing Journal, 29(9), 776-799.

Kilgore, A., Radich, R., \& Harrison, G. (2011). The Relative Importance of Audit Quality Attributes. Australian Accounting Review, 21(3), 253-265.

Lee, D. K. J. S. (2015). Auditor tenure and audit quality an empirical analysis at audit firm and audit partner level for the German market, 619.

Li, Y., Stokes, D., Taylor, S., \& Wong, L. (2009). Audit quality, accounting attributes and the cost of equity capital. Working Paper, (OCTOBER).

Lim, C. Y., \& Tan, H. T. (2010). Does auditor tenure improve audit quality? Moderating effects of industry specialization and fee dependence. Contemporary Accounting Research, 27(3), 923-957.

Lin, L., \& Kong Tepalagul, N. (2015). Auditor Independence and Audit Quality: A Literature Review. The Effects of Brief Mindfulness Intervention on Acute Pain Experience: An Examination of Individual Difference, 1, 1-54.

Malaysian Institute of Accountants. (2016). The Future of Audit. Accountants Today, (Sept/Oct), 10-15.

Muliati, M., Mayapada, A.G, Parwati, N.M.DS, Ridwan, R., \& Samilta, D. (2021). Does Audit Matter in Earnings Quality of Indonesia Banks?. Journal of Asian Finance, Economics and Business, 8(2), 0143-0150

Patrick, Z., Vitalis, K., \& Mdoom, I. (2017). Effect of auditor independence on audit quality: A review of literature. International Journal of Business and Management Invention, 6(3), 51-59.

Prayogo, B., \& Agoes, S. (2017). Role of Audit Regulation on The Effect of Corporate Governance and Audit Quality on Earnings Management. International Journal of Sustainable Development, 10(10).

PWC - Indonesia (2015). Overview of Audit Quality Indicators Initiatives, (November), 1-6.

PWC - Indonesia. (2017). Transparency report: A conversation on transparency, quality, and value, (September). 
Rahmina, L. Y., Agoes, S., Rohami, S., Wan Nordin, W. H., Mohd. 'Atef, M. Y., \& Md Hairi, M. H. (2015). An empirical analysis of auditor independence and audit fees on audit quality. International Journal of Management and Business Studies, 3(3), 99-109.

Rohami, S., Wan Nordin, W. H., Mohd. 'Atef, M. Y., \& Md Hairi, M. H. (2009). Audit Firm Tenure and Auditor Reporting Quality: Evidence in Malaysia. International Business Research, 2(2), 99-109.

Saputra, W. (2015). The Impact Of Auditor's Independence On Audit Quality : A Theoretical Approach. International Journal of Scientific \& Technology Research, 4(12, DECEMBER 2015).

Sarwoko, I., \& Agoes, S. (2014). An Empirical Analysis of Auditor's Industry Specialization, Auditor's Independence and Audit Procedures on Audit Quality: Evidence from Indonesia. Procedia - Social and Behavioral Sciences, 164(August), 271-281.

Siregar, S. V., Amarullah, F., Wibowo, A., \& Anggraita, V. (2012). Audit tenure, auditor rotation, and audit quality: The case of Indonesia. Asian Journal of Business and Accounting, 5(1), 55-74.

Skinner, D. J., \& Srinivasan, S. (2012). Audit quality and auditor reputation: Evidence from Japan. The Accounting Review, $87(5), 1737-1765$.

Srinivasan, S., Wahid, A. S., \& Yu, G. (2015). Admitting mistakes: Home country effect on the reliability of restatement reporting. The Accounting Review, 90(3), 1201-1240.

Stanley, J. D., \& DeZoort, F.T. (2007). Audit firm tenure and financial restatements: An analysis of industry specialization and fee effects. Journal of Accounting and Public Policy, 26(2), 131-159.

Suseno, N. S. (2013). An empirical analysis of auditor independence and audit fees on audit quality. International Journal of Management and Business Studies, 3(3), 82-87.

Tepalagul, N., \& Lin, L. (2015). Auditor Independence and Audit Quality: A Literature Review. Journal of Accounting, Auditing \& Finance, 30(1), 101-121.

van Raak, J., \& Thürheimer, U. (2016). Opportunities to improve the measurement of audit quality: A call for collaboration between the profession and academics. Mab, 90(9), 352-358.

Wooten, T. C., \& Colson, R. H. (2003). Research About Audit Quality. CPA Journal, 73(1), 48. Retrieved from

Zhang, Y., Zhou, J., \& Zhou, N. (2007). Audit committee quality, auditor independence, and internal control weaknesses. Journal of Accounting and Public Policy, 26(3), 300-327. 


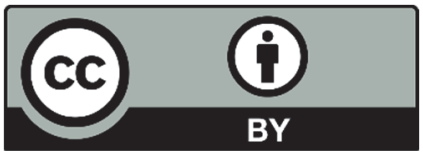

(C) 2021 by the authors; licensee Growing Science, Canada. This is an open access article distributed under the terms and conditions of the Creative Commons Attribution (CC-BY) license (http://creativecommons.org/licenses/by/4.0/). 